\title{
EFFICACY OF CERTAIN ACARICIDES AGAINST Tetranychus urticae AND THEIR SIDE EFFECTS ON NATURAL ENEMIES, Phytoseiulus persimilis AND Stethorus gilvifrons Alyaa A.Tawfik ${ }^{1}$ and Laila R. A. Elgohary ${ }^{2}$ \\ 1 Plant Protection Research Institute, Agricultural Research Center, Dokki, Giza, Egypt. \\ ${ }^{2}$ Pesticide Dept., Faculty of Agriculture, Mansoura University, Egypt.
}

\begin{abstract}
The objective of this study was conducted to determine the efficacy of five acaricides; Abamectin, Emamectin benzoate, Acequinocyl, Chlorfenapyr and Hexythiazox against Tetranychus urticae and its natural enemies, Phytoseiulus persimilis and Stethorus gilvifrons. The tested acaricides were arranged in a descending order of speed of action against T. urticae as follows: Abamectin, Emamectin benzoate, Acequinocyl, Chlorfenapyr and Hexythiazox with $\mathrm{LT}_{50}$; 1.77 , $2.85,3.16,3.94$ and 4.55 days, however, the corresponding speed action index were $100.00,62.11,56.01,44.92$ and $38.90 \%$, respectively. Concerning $P$. persimilis, Abamectin was the slowest Speed of action compared with other tested acaricides $\left(L T_{50}=4.31\right.$ days $)$ followed by Acequinocyl, Emamectin benzoate, Chlorfenapyr and Hexythiazox with $\mathrm{LT}_{50} ; 2.90,1.78,1.38$ and 1.03 days and the corresponding speed action index of $23.90,35.52,57.87,74.64$ and $100.00 \%$, respectively. Also, Abamectin recorded the lowest Speed of action against $S$. gilvifrons $\left(L T_{50}=4.16\right.$ days) followed by Acequinocyl, Emamectin benzoate, Hexythiazox and Chlorfenapyr with $\mathrm{LT}_{50} ; 2.81,2.61,1.89$ and 1.85 days and the corresponding speed action index of 44.47, 65.84, 70.88, 97.88 and $100.00 \%$, respectively. Reviewing the obtained results, it can be noticed that Abamectin was the quickest in its action against $T$. urticae and the slowest against $P$. persimilis and $S$. gilvifrons compared with other tested acaricides. The efficacy of the tested acaricides on the population density of $T$. urticae could be arranged according to the general mean of reduction percentage in a descending order as follows: Abamectin, Acequinocyl, Hexythiazox, Emamectin benzoate and Chlorfenapyr which recorded 83.29, 66.06, 56.40, 53.02 and $25.67 \%$ reduction, respectively.
\end{abstract}

\section{INTRODUCTION}

The approach to improve the pest management, especially in the direction of integrated biological and chemical methods is to include the impact of natural enemies and pesticides. Therefore, the knowledge of the effects of pesticides on beneficial species for particular crops is very important. Integrating biological control with chemicals in the spider mite management programs is particularly attractive because biological control of these pests has been implemented successfully on various horticultural crops (Helle and Sabelis, 1985). The two-spotted spider mite, Tetranychus urticae (Acari: Tetranychidae) is a polyphagous mite that feeds on parenchym cells of many agricultural crops (Tomczyk and Kropczynska1985). Two important groups of spider mite predators are predatory mites (Acarina: Phytoseiidae) 
and coccinellid beetles of the genus Stethorus (Coleoptera: Coccinellidae) (Roy et al., 2005). Predatory mites of the family Phytoseiidae are effective as biological control agents in agricultural systems (Hoy et al., 1983). Phytoseiulus persimilis Athias-Henriot, is worldwide used in biological control programs in the world (Gerson et al., 2003). The predatory ladybird beetle, Stethorus gilvifrons (Mulsant) is a predator preying on different life stages of two-spotted spider mites (Hajizadeh et al.1992; Afshari et al. 2001; Kheradpir et al. 2006). Numerous acaricides are used to control this pest, and consequently it has developed resistance to several acaricides. T. urticae outbreaks are induced by a number of factors, frequently by the use of pesticides non-selective towards its natural enemies (McMurtry et al., 1970). In recent years, different strategies have been developed to manage the twospotted spider mite, T. urticae Koch (Bostanian et al., 2003). Since resistance to acaricides in $T$. urticae spread rapidly, biological control tactics are crucial to manage spider mite populations (Gerson and Weintraub 2007). However, it is important to study the predators as natural enemies when considering control of $T$. urticae. Thus, some trials in laboratory and field to assess the effects of five acaricides against $T$. urticae and its natural enemies, $P$. persimilis and S. gilvifrons were conducted.

\section{MATERIALS AND METHODS}

\section{Rearing prey mite}

The two spotted spider mite, T. urticae was reared on kidney bean (Phaseolus vulgaris L.) planted in a greenhouse (3-4 weeks after germination), and maintained at $25-28^{\circ} \mathrm{C}, 40-60 \% \mathrm{RH}$ with a photoperiod of $16 \mathrm{~L}: 8 \mathrm{D}(\mathrm{h})$ Each population was colonized before experiments in the laboratory.

\section{Rearing predators}

The phytoseiid predator $P$. persimilis was reared in plastic tray $(25 \mathrm{x}$ $25 \mathrm{~cm})$ placed in a plastic box $(40 \times 60 \times 7 \mathrm{~cm})$ containing water to prevent mite escape. Fresh kidney bean leaves heavily infested with prey were added to the tray every 1 or 2 days and old leaves were removed once a week. The $P$. persimilis rearing was conducted under laboratory conditions of $23 \pm 2{ }^{\circ} \mathrm{C}$, 50-70\% R.H. and L16:D8 photoperiod. The acarophagous Ladybird, S. gilvifrons (Mulsant) was reared as a predator of spider mites under the same conditions.

\section{Acaricides and application}

The tested active ingredients, their trade names, formulations and applied concentrations are listed in Table 1. All of the concentrations are within the range of recommended rate for field use. 
Table 1: Tested acaricides:

\begin{tabular}{|l|c|c|c|}
\hline Active ingredient & Trade Name & $\begin{array}{c}\text { \% a.i. and } \\
\text { formulation }\end{array}$ & $\begin{array}{c}\text { Concentration } \\
\mathbf{m l} / \mathbf{1 0 0} \text { } \text { water }\end{array}$ \\
\hline Hexythiazox & Delta care & $10 \%$ EC & 50 \\
\hline Emamectin benzoate & Gentraxiem & $5 \%$ SL & 30 \\
\hline Acequinocyl & Canemite & $15 \%$ SC & 100 \\
\hline Abamectin & Agremic gold & $8.4 \%$ SC & 60 \\
\hline Chlorfenapyr & Payerseed & $36 \%$ SC & 35 \\
\hline
\end{tabular}

\section{Speed of action of tested acaricides:}

The leaf disk assay was conducted using method described earlier by Pree et al., (1989). The kidney bean leaf disks $(2.5 \mathrm{~cm}$ diameter) cut from seedlings grown in a glass house with no chemical usage were dipped in concentration suggested for field applications according to APC 2010, Egypt of the various acaricides for 30 seconds. The discs were put on wet cotton wool in petri-dish and kept under constant conditions $\left(\left(25 \pm 2^{\circ} \mathrm{C}, 65 \pm 5 \% \mathrm{RH}\right.\right.$ and 16:8 photoperiod). Ten female adults (one day old) of $T$. urticae were transferred on each disk with a fine brush. Control disks were dipped in tap water. Tests were repeated 5 times for each treatment. Mortality of mites treated with acaricides in all tests was assessed at different time intervals during 7 days after treatment. Data were corrected according to Abbott formula (1925). The half lethal time values $\left(\mathrm{LT}_{50}\right)$ were computed by Ldp Line program (Finny 1971). Also, the speed action index was measured by comparing the tested compound with the quickest speed of action compound. The same technique was occurred with the two predators $P$. persimilis and $S$. gilvifrons.

\section{Effect of tested acaricides on population density:}

Each evaluated chemical was mixed with distilled water to achieve a solution of the desired concentration. A100 ml volume of each solution was sprayed onto kidney bean to run-off using a $200 \mathrm{ml}$ hand trigger sprayer with adjustable nozzle set to mist position. Untreated plants were sprayed with distilled water. Three plants were used for each pot. The kidney been were planted in November 2014 and grown in $3.81 \mathrm{~cm}$ in diameter plastic pots under field conditions. Drip irrigation and nutrients were applied uniformly to all plants and no pesticides were used prior to the experimental applications. The plants remained outdoors under field conditions. Each acaricide was applied at the concentration suggested for field applications according to APC 2010, Egypt. Alive T. urticae was counted and recorded at pre-spraying and after $3,6,10,14,17,24$ and 30 days of application. Lower surface of the leaves was examined carefully using stereomicroscope. Five replicates were used for each treatment and the control. Percentage of reduction was estimated according to the equation of Henderson and Tilton (1955).

Statistical analysis

Data of population density were subjected for one way analysis of variance (ANOVA), and the means were separated using Duncan's multiple range Test CoHort Software 2004. 


\section{RESULTS}

\section{I -Speed of action:}

Speed of action of tested acaricides against adult $T$. urticae, $P$. persimilis and $S$. gilvifrons at the recommended rates at different time intervals days are documented in Tables 2, 3 and 4. Data in table 2 show that the speed of action of Abamectin was very fast. Within 1.77 days after treatment with Abamectin, approximately half of all $T$. urticae adults were killed and after 5 days all $T$. urticae adults were killed, whereas Hexythiazox recorded the lowest speed of action ( $\mathrm{LT}_{50}=4.55$ days). The tested acaricides were arranged in a descending order of speed of action (from the highest to the lowest speed of action) as follows: Abamectin, Emamectin benzoate, Acequinocyl, Chlorfenapyr and Hexythiazox with $\mathrm{LT}_{50}$; 1.77, 2.85, 3.16, 3.94 and 4.55 days, however, corresponding speed action index were 100.00, $62.11,56.01,44.92$ and $38.90 \%$, respectively.

Concerning Speed of action against the predatory mite $P$. persimilis, Data in Table 3 indicate that Abamectin was the slowest speed of action compared with other tested acaricides $\left(\mathrm{LT}_{50}=4.31\right.$ days) followed by Acequinocyl, Emamectin benzoate, Chlorfenapyr and Hexythiazox with $\mathrm{LT}_{50}$; $2.90,1.78,1.38$ and 1.03 days and the corresponding speed action index were $23.90,35.52,57.87,74.64$ and $100.00 \%$, respectively.

Similarly, Data in Table 4 show that Abamectin recorded the lowest Speed of action against the insect predator $S$. gilvifrons $\left(\mathrm{LT}_{50}=4.16\right.$ days) followed by Acequinocyl, Emamectin benzoate, Hexythiazox and Chlorfenapyr with $\mathrm{LT}_{50} ; 2.81,2.61,1.89$ and 1.85 days and the corresponding speed action index were 44.47, 65.84, 70.88, 97.88 and $100.00 \%$, respectively.

\section{II - Field efficacy of the tested acaricides against $T$. urticae:}

As shown in Table (5), all tested acaricides significant reduced the population density of the two spotted spider mite, $T$. urticae compared with control. Concerning the initial effect (after one day of spraying), Abamectin and Acequinocyl were the most striking, which caused 57.97 and $57.88 \%$ reduction, respectively. While the lowest effect obtained with Hexythiazox which caused $37.38 \%$ reduction in population density compared with control. Abamectin reached the highest efficacy at tenth day (92.73\% reduction),

\section{DISCUSSION}

Reviewing the obtained results, it can be noticed that the speed of action of Abamectin was the quickest against $T$. urticae and the slowest against $P$. persimilis and $S$. gilvifrons than the other tested acaricides. 
J. Plant Prot. and Path., Mansoura Univ., Vol.6 (3), March, 2015

2-3 
Several investigators have found that exposure to abamectin residues does not have a significant effect on $P$. persimilis survival (Oomen et al., 1991; Shipp et al., 2000; Zhang and Sanderson, 1990). Abamectin causes significant mortality and reduction in the mobility and fecundity of $T$. urticae (Zhang and Sanderson, 1990). Residual activity of Abamectin is likely to decrease more quickly in outdoor environments than indoor environments (Wright et al., 1984). Selective use of acaricides may create a favorable situation for release of $P$. persimilis by reducing $T$. urticae to manageable levels, providing that other environmental conditions are suitable. While treatment with acaricides that have long residual toxicity may be required to suppress high-density of spider mite population, their use may promote spider mite resistance. Acaricides that have short residual toxicities can be used in combination with predators to reduce large population of spider mites, but the timing of application and predator release is critical (Osborne and petitt, 1985). Exposure to abamectin, Gowan 1725, hexythiazox, horticultural oil, neem oil, pyridaben and spinosad residues at typical rates did not cause $P$. persimilis mortality 24 hours after application. However, abamectin residue did result in significant mortality to adult $T$. urticae 3, 7 and 14 days after application (Cote et al., 2002). Al-Zoubi and Çobanoğlu (2007) reported that the combination of hexythiazox with releasing of $P$. persimilis gave well control on spider mite, T. urticae when compared with chemical and predatory mite alone under greenhouse conditions. Nadimi et al., (2008) cited that the total effect values of all concentrations of hexythiazox were below the lower threshold thus it could be considered a harmless acaricide to this predatory mite. In contrast, the total effect of all concentrations of fenpyroximate, and field, as well as, one half the field concentration of abamectin were found toxic to predatory mite and above upper threshold. AlZoubi (2010) found that, Hexythiazox was evaluated as harmless after 24 hours and moderately harmful after 72 hours to $P$. persimilis. For this reason, hexythiazox is suggested to be suitable in IPM program and ensure the preservation of predatory strains into local agroecosystem. Sanatgar et al., 2011 cited that the overall conclusion shows that this acaricide can be used against $T$. urticae without inducing the adverse effect on population growth parameters of its predator, P. persimilis. Irigaray et al., (2007) found that, Abamectin was slightly persistent, while Acequinocyl was short lived to $P$. persimilis.

The efficacy of the tested acaricides in this study could be arranged according to the general mean of reduction percentages of the population density of $T$. urticae in a descending order as follows: Abamectin, Acequinocyl, Hexythiazox, Emamectin benzoate and Chlorfenapyr they were $83.29,66.06,56.40,53.02$ and $25.67 \%$ reduction, respectively.

Abd-Elhady and Heikal (2011) evaluate the selectivity of three acaricides sprayed at 1 and $1 / 2$ field recommended rate on apple orchards on motiles of both two-spotted spider mite $T$. urticae and its predator $P$. persimilis. Results showed that, fenpyroximate and abamectin were found to be very toxic to the predatory mite at recommended field rate after 30 days and unfavorably selective (more toxic to $P$. persimilis). In conclusion, fenpyroximate and abamectin should be used carefully in Integrated Pest 
Management programs. Salman (2007) cited that, as far the possible side effect of tested pesticides on different stages of the insect predator, $S$. gilvifrons. The result evoked that hexythiazox, fenpyroximate and chlorfenapyr were less toxic to all predator stages (egg, larvae and adult) under Laboratory condition. Also, revealed that the same compounds appear highly initial kill against the two-spotted spider mite $T$. urticae on watermelon, eggplant and squash under field conditions. The reduction percentages were more than $90 \%$. However, moderate effects on the predator S. gilvifrons were observed. Mortality didn't exceed more than sixteen's percentage. Fortunately the predator were more tolerant comparing with mite. Kim and Yoo (2002) Adult female predators survived on a diet of spider mites treated with bifenazate, acequinocyl, chlorfenapyr, flufenoxuron and fenbutatin oxide, and their fecundity, prey consumption and the sex ratio of the progeny were not substantially affected so, its acaricides appeared to be the promising candidates for usein integrated mite management programs where $P$. persimilis is the major natural enemy. Moreover, they reported that feeding on T. urticae intoxicated with abamectin reduced $50 \%$ of the reproductive rate of female P. persimilis. Abd El-Mageed et al., (2013) reported that chlorfenapyr, ethion and etoxazole are much less toxic to $P$. persimilis adult females than to $T$. urticae adult females, and the difference between the compounds may be due to their mode of actions.

In addition, the predators alone may not be able to maintain spider mite population below an economic injury level for an extended period of time (Kim et al., 1997; Ibrahim and Yee 2000). In the presence of chemical applications, biological control of spider mites may be achieved by the selective use of the pesticides that are more toxic to pest species than to natural enemies (Spollen and Isman 1996). Thus, selective acaricides are needed to adjust the prey/predator ratio and to maintain adequate long-term control efficacy. In many cases, the combined use of chemical and biological control might provide the best approach for both managing pest populations and minimizing selection for resistance (Gentz et al., 2010). The Integrated Pest Management (IPM) which is based on selective toxicity of the phytophagous mites and harmless to predatory mite, became the most relevant strategy of plant protection (Leake, 2000; Linquist, 2000 and Klassen, 2000). 
Alyaa A.Tawfik and Laila R. A. Elgohary

4- 
J. Plant Prot. and Path., Mansoura Univ., Vol.6 (3), March, 2015

5- 


\section{REFERENCES}

Abbott W.S. (1925). A method of computing the effectiveness of an insecticide. J. Econ. Entomol. 18: 265 - 267.

Abd El-Mageed, A.E.M.; A.A. Tawfik and E.E. Abohatab (2013). Assessment of bioassay techniques and residual effect of certain acaricides against the two spotted spider mite, Tetranychus urticae Koch and the predatory mite, Phytoseiulus persimilis Athias-Henriot. ACARINES, Vol. 7: 63-70.

Abd-Elhady, H.K. and H.M.M. Heikal (2011). Selective Toxicity of Three Acaricides to the Two-Spotted Spider Mite Tetranychus urticae and Predatory Mite Phytoseuilus persimilis in Apple Orchards. Journal of Entomology, 8: 574-580.

Afshari, A.; M.S Mossadegh.and K. Kamali (2001). Feeding behaviors of the ladybird beetle, Stethorus gilvifrons (Mulsant), and effect of different factors on its feeding rate in laboratory condition. Sci. J. Agric. 23, 7090.

Al-Zoubi, S. (2010). Responses of the Two-Spotted Spider Mite Tetranychus urticae Koch (Acari: Tetranychidae) and Predatory Mite Phytoseiulus persimilis Athias-Henriot (Acari: Phytoseiidae) to Some Pesticides. Jordan Journal of Agricultural Sciences, Vol. 6(3): 365-372.

Al-Zoubi, S. and S. Çobanoğlu (2007). Effects of Sublethal Dose of Different Pesticides on the Two-spotted Spider Mite "Tetranychus urticae Koch" and its Predatory Mites under Greenhouse Conditions. World Journal of Agricultural Sciences, 3(6): 764-770.

APC 2010. Agricultural Pesticides Committee, Ministry of Agriculture, Egypt. http://www.apc.gov.eg. Accessed 25 February 2010.

Bostanian, N.J.; M. Trudeau and J. Lasnier (2003). Management of the twospotted spider mite, Tetranychus urticae (Acari: Tetranychidae) in eggplant fields. Phytoprotection 84:1-8.

Cohort Software (2004). CoStat. www.cohort.com Montery, California, USA.

Cote, K.W.; E.E. Lewis and P.B. Schultz (2002). Compatibility of acaricide residues with Phytoseiulus persimilis and their effect on Tetranychus urticae. HortScience 37:906-909.

Finney D.J. (1971). Probit analysis. A Statistical Treatment of the Sigmoid Response Curve. 7th Ed., Cambridge Univ. Press, England.

Gentz, M.C.; G. Murdoch and G.F. King (2010). Tandem use of selective insecticides and natural enemies for effective, reduced-risk pest management. Biol. Control, 52: 208-215.

Gerson, U. and P.G. Weintraub (2007). Mites for the control of pests in protected 1 cultivation. Pest Management Science 63, 658-676.

Gerson, U.; R.L. Smiley and R. Ochoa (2003). Mites (Acari) for Pest Control. Blackwell Science, Malden USA.

Hajizadeh, J.; K. Kamali and M.S. Mossadegh (1992). Studies on the feeding behavior of Stethorus gilvifrons Mulsant (Col.: Coccinellidae). Sci. J. Agric. 18, 71-88. 
Helle, W. and M.W. Sabelis (1985). Spider Mites: Their Biology, Natural Enemies and Control. Vol. 1B. Elsevier, Amsterdam.

Henderson, C.F. and E.W. Tilton (1955). Test with acaricides against the brown wheat mite. J. Econ. Entomol. Vol. 48: 157-161.

Hoy, M.A.; G.L. Cunningham and L. Knutson (1983). Biological Control of Pests by Mites. Univ. Calif. Div. Agric. Nat. Res. Publ., 3304, Berkeley, CA.

Ibrahim, Y.B. and T.S. Yee (2000). Influence of sublethal exposure to abamectin on the biological performance of Neoseiulus longispinosus (Acari: Phytoseiidae). J. Econ. Entomol. 93: 1085-1089.

Irigaray F.; F.G. Zalom and P.B. Thompson (2007). Residual toxicity of acaricides to Galendromus occidentalis and Phytoseiulus persimilis reproductive potential. Biological Control. 40: 153-159.

Kheradpir, N.; J. Khalghani; H. Ostovan and M.R. Rezapanah (2006). Feeding rate of Stethorus gilvifrons on Tetranychus urticae in three greenhouse cucumber cultivars with different resistance levels. IOBC/WPRS Bull. 29, 139-143.

Kim, D.I.; S.C. Lee; C.H. Paik; S.S. Kim and K.C. Ma (1997). Population fluctuation of Tetranychus kanzawai and their natural enemies and related susceptibility of some pesticides to Amblyseius womersleyi and T. kanzawai. J. Kor. Tea Soc. 3: 83-93.

Kim, S.S. and S.S. Yoo (2002). Comparative toxicity of some acaricides to the predatory mite, Phytoseiulus persimilis and the twospotted spider mite, Tetranychus urticae BioControl .47: 563-573.

Klassen, W. (2000). Area-Wide Approaches to Insect Pest Intervention: History and Lessons. In: Area-Wide Control of Fruit Flies and Other Insect Pests, Tan, K.H. (Ed.). Penerbit University Sains Malaysia, Penang, Malaysia, pp: 21-38.

Leake, A. (2000). The development of integrated crop management in agricultural crops: Comparisons with conventional methods. Pest Manage. Sci., 56: 950-953.

Linquist, D.A. (2000). Pest Management Strategies: Area-Wide and Conventional. In: Area-Wide Control of Fruit Flies and Other Insect Pests, Tan, K.H. (Ed.). Penerbit University Sains Malaysia, Penang, Malaysia, pp: 13-20.

McMurtry, J.A.; C.B. Huffaker and M. Van de Vrie (1970). Ecology of tetranychid mites and their natural enemies: a review. 1. Tetranychid enemies, their biological characteristics and the impact of spray practices. Hilgardia 40, 331-390.

Nadimi, A.; K. Kamali, M. Arbabi and F. Abdoli (2008). Side-effects of three acaricides on the predatory mite, Phytoseiulus persimilisathias-henriot (Acari: Phytoseiidae) under laboratory conditions. Munis Entomol. Zool., 3: 556-567.

Oomen, P.A.; G. Romeijn and G.L. Wiegers (1991). Side-effects of 100 acaricides on the predatory mite Phytoseiulus persimilis, collected and evaluated according to the EPPO guideline. Bull Europ Medit PI Protect Org (OEPP/EPPO) 21: 701-712. 
Osborne, L.S. and F.L. Petitt (1985). Insecticidal soap and the predatory mite, Phytoseiulus persimilis (Acari: Phytoseiidae), used in management of the two-spotted spider mite (Acari: Tetranychidae) on greenhouse grown foliage plants. J. Econ. Entomol. 78: 687-691.

Pree, D.L.; K.J. Cole and P.A. Fisher (1989). Comparison of leaf disc and petri dish assays for the assessment of dicofol resistance in populations of European red mite (Acari: Tetranychidae) from southern Ontario. Can. Entomol. 12: 771-776.

Roy, M.; J. Brodeur and C. Cloutier (2005). Seasonal activity of the spider mite predators Stethorus punctillum (Coleoptera: Coccinellidae) and Neoseiulus fallacis (Acarina: Phytoseiidae) in raspberry, two predators of Tetranychus mcdanieli (Acarina:Tetranychidae). Biol. Control. 34, 47-57.

Salman, M.S. (2007). Comparative toxicological studies of certain acaricides on two spotted spider mite Tetranychus urticae (Koch.) and its predator Stethorus gilvifrons (Mulsant). Ph.D. Thesis Fac. of Agric. Suez Canal University. Egypt.

Sanatgar, E.; R. V. Shoushtari; A.A. Zamani; M. Arbabi and E.S. Nejadian (2011). Effect of Frequent Application of Hexythiazox on Predatory Mite Phytoseiulus persimilis Athias - Henriot (Acari: Phytoseiidae). Academic Journal of Entomology 4 (3): 94-101.

Shipp, J.L.; K. Wang and G. Ferguson (2000). Residual toxicity of avermectin bl and pyridaben to eight commercially produced beneficial arthropod species used for control of greenhouse pests. Biological Control 17: 125-131.

Spollen, K.M. and M.B. Isman (1996). Acute and sublethal effects of a neem insecticide on the commercial biological control agents Phytoseilus persimilis and Amblyseius cucumeris (Acari: Phytoseiidae) and Aphidoletes aphidimyza (Diptera: Cecidomyiidae). J. Econ. Entomol. 89:1379-1386.

Tomczyk, A. and D. Kropczynska (1985). Effects on the host plant. p. 317329. In W. Helle and M.W. Sabelis (ed.) Spider mites, their, biology, natural enemies and control, Vol. IA. Elsevier, New York.

Wright, D.J.; I.J. Roberts; A. Androher; A.St.J. Green and R. A. Dybas (1984). The residual activity of abamectin (MK-936) against Tetranychus urticae Koch on cotton. Meded. Fac. Landbouwwet. Rijksuniv. 50:633637.

Zhang, Z. and J. P. Sanderson (1990). Relative toxicity of abamectin to the predatory mite Phytoseiulus persimilis (Acari: Phytoseiidae) and twospotted spider mite (Acari: Tetranychidae). J. Econ. Entomol. 83: 1783-1790. 


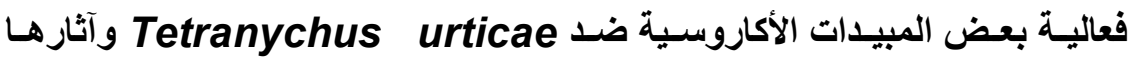

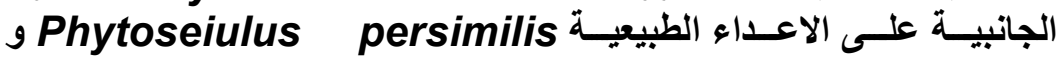 Stethorus gilvifrons}

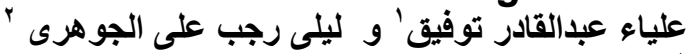

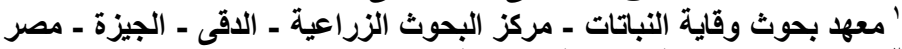

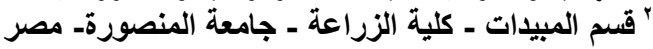

اجريت هذه الدراسة بهدف تقييم فعالية خمسة مبيدات أكاروسية وهى ابـامكتين، ايماميكتين

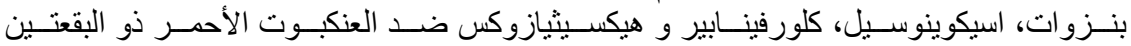
و و العـدويين الطبيعيبن Tetranychus urticae

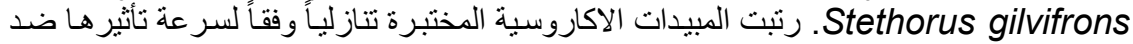

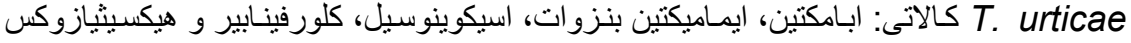

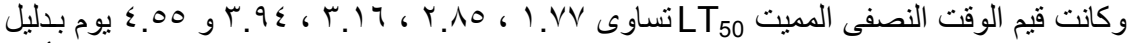

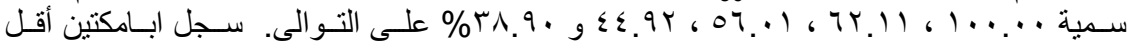

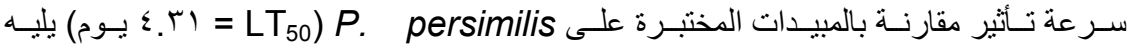

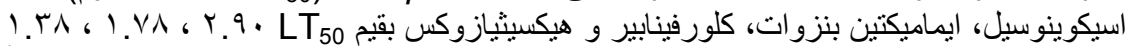

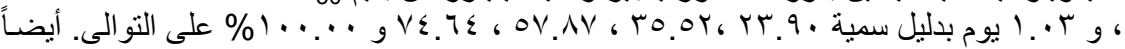
سـجل ابـامكتين أقل سـر عة تأثير ضـد

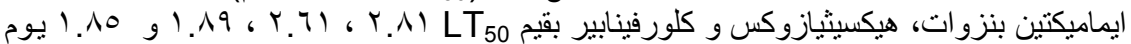

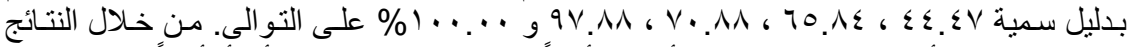

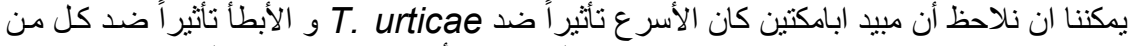

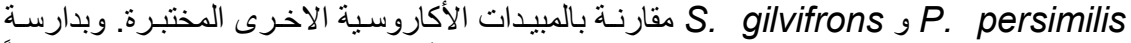

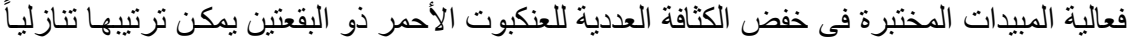

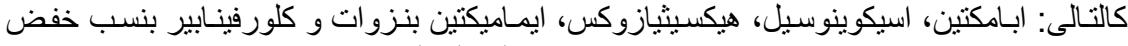
\% 
Alyaa A.Tawfik and Laila R. A. Elgohary 


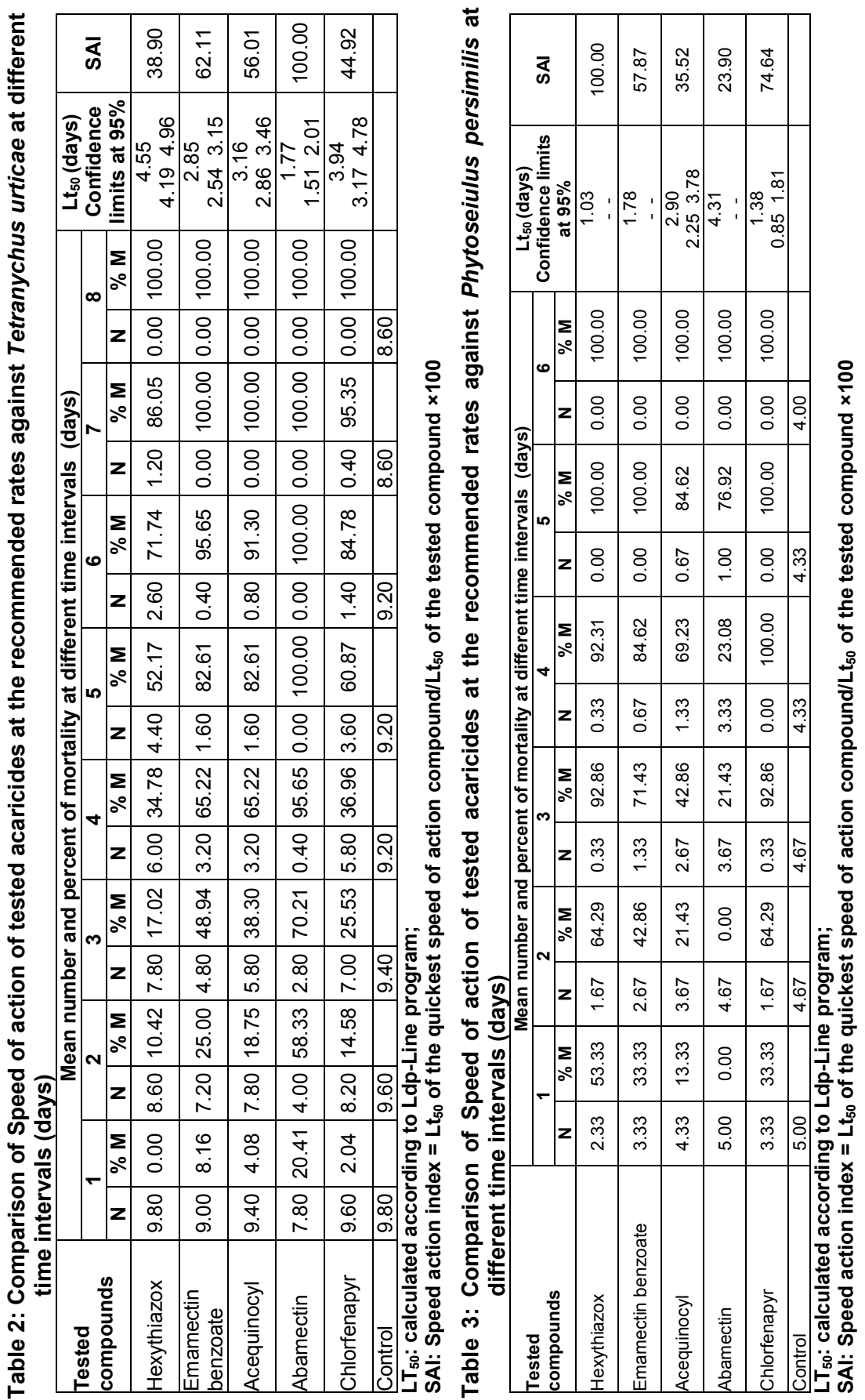




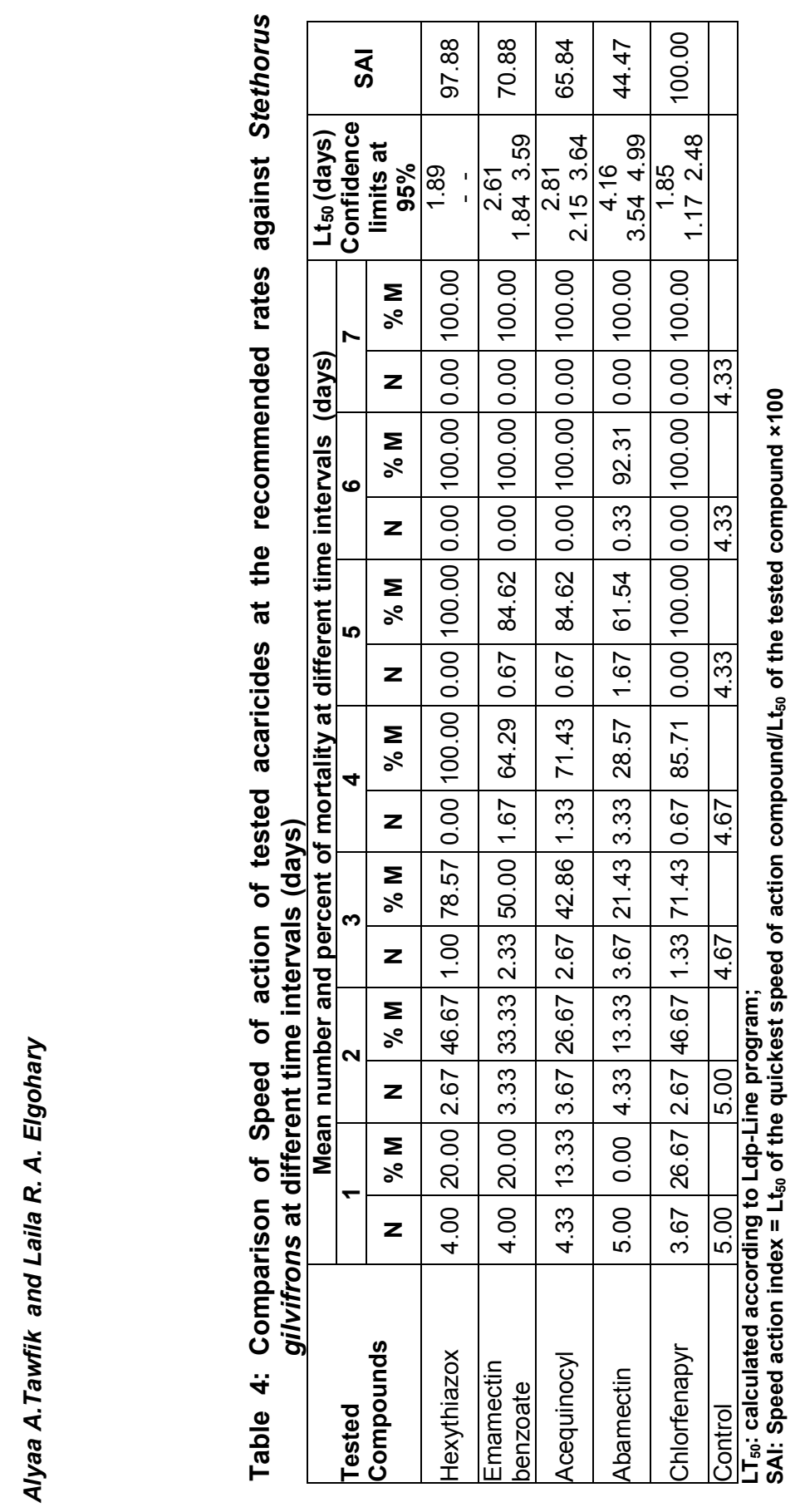




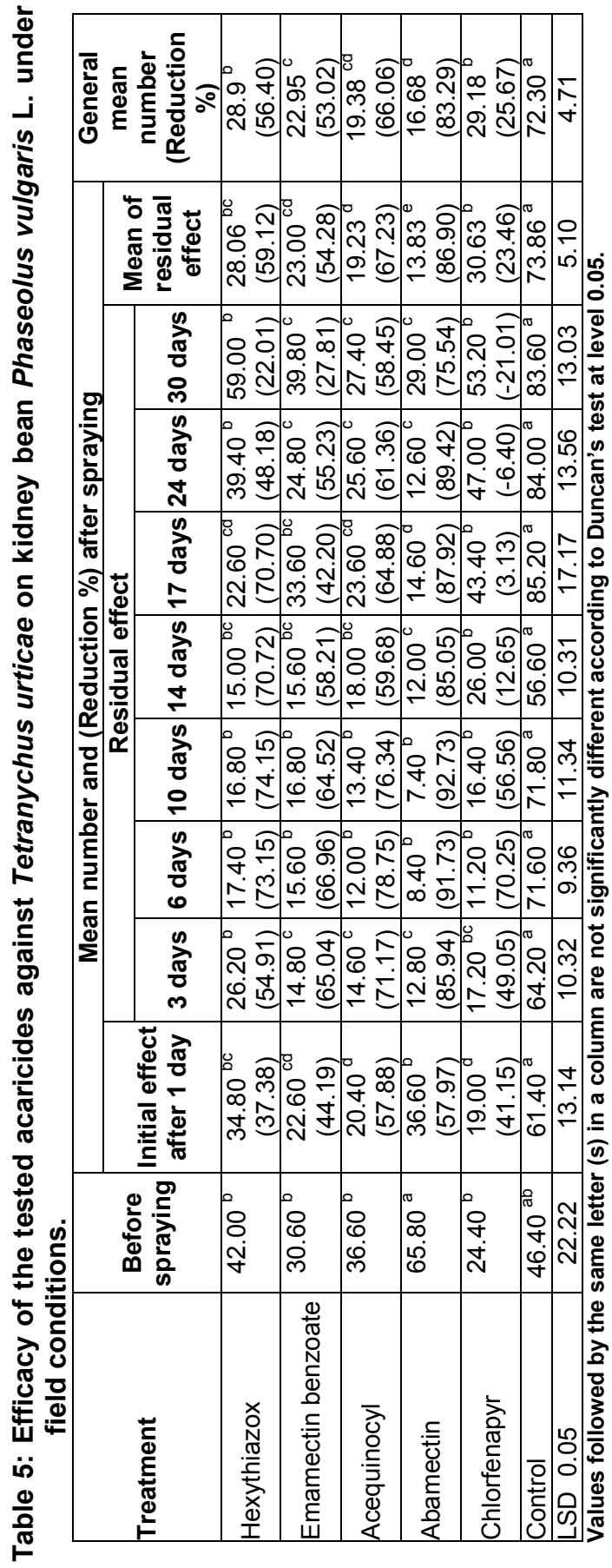

